
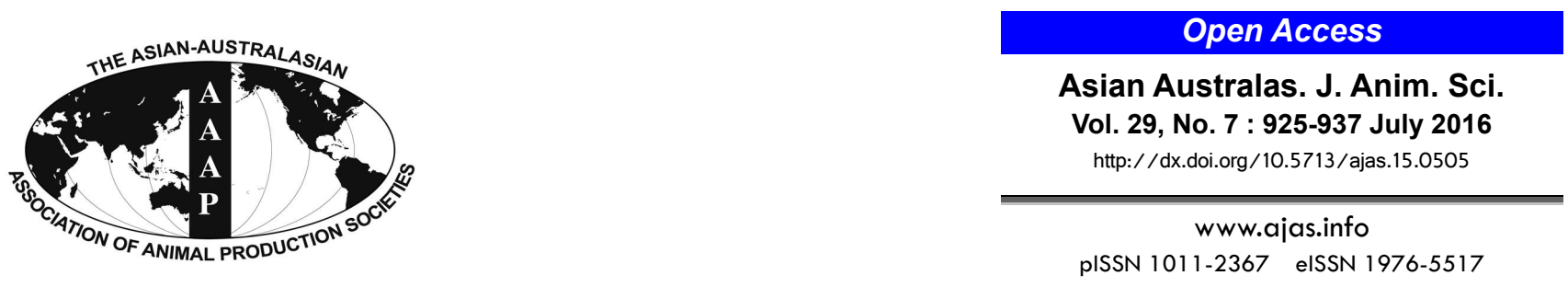

\title{
Production of Transgenic Pigs with an Introduced Missense Mutation of the Bone Morphogenetic Protein Receptor Type IB Gene Related to Prolificacy
}

\author{
Xueyan Zhao, Qiang Yang, Kewei Zhao, Chao Jiang, Dongren Ren, Pan Xu, Xiaofang He, Rongrong Liao, \\ Kai Jiang, Junwu Ma, Shijun Xiao, Jun Ren, and Yuyun Xing* \\ State Key Laboratory for Pig Genetic Improvement and Production Technology, \\ Jiangxi Agricultural University, Nanchang 330045, China
}

\begin{abstract}
In the last few decades, transgenic animal technology has witnessed an increasingly wide application in animal breeding. Reproductive traits are economically important to the pig industry. It has been shown that the bone morphogenetic protein receptor type IB (BMPR1B) A746G polymorphism is responsible for the fertility in sheep. However, this causal mutation exits exclusively in sheep and goat. In this study, we attempted to create transgenic pigs by introducing this mutation with the aim to improve reproductive traits in pigs. We successfully constructed a vector containing porcine BMPR1B coding sequence (CDS) with the mutant G allele of A746G mutation. In total, we obtained 24 cloned male piglets using handmade cloning (HMC) technique, and 12 individuals survived till maturation. A set of polymerase chain reactions indicated that 11 of 12 matured boars were transgene-positive individuals, and that the transgenic vector was most likely disrupted during cloning. Of 11 positive pigs, one (No. 11) lost a part of the terminator region but had the intact promoter and the CDS regions. cDNA sequencing showed that the introduced allele (746G) was expressed in multiple tissues of transgene-positive offspring of No.11. Western blot analysis revealed that BMPR1B protein expression in multiple tissues of transgene-positive $F_{1}$ piglets was 0.5 to 2-fold higher than that in the transgene-negative siblings. The No. 11 boar showed normal litter size performance as normal pigs from the same breed. Transgene-positive $F_{1}$ boars produced by No. 11 had higher semen volume, sperm concentration and total sperm per ejaculate than the negative siblings, although the differences did not reached statistical significance. Transgene-positive $\mathrm{F}_{1}$ sows had similar litter size performance to the negative siblings, and more data are needed to adequately assess the litter size performance. In conclusion, we obtained 24 cloned transgenic pigs with the modified porcine BMPR1B CDS using HMC. cDNA sequencing and western blot indicated that the exogenous BMPR1B CDS was successfully expressed in host pigs. The transgenic pigs showed normal litter size performance. However, no significant differences in litter size were found between transgene-positive and negative sows. Our study provides new insight into producing cloned transgenic livestock related to reproductive traits. (Key Words: Transgenic, Handmade Cloning, Pig, BMPR1B, Coding Sequence, Reproductive Traits)
\end{abstract}

\section{INTRODUCTION}

Since the emergence of the world's first transgenic animals (Gordon et al., 1980), animal transgenic techniques have attracted researchers' interest for decades. A number of transgenic animal methods like pronuclear microinjection, viral-mediated DNA transfer and sperm-mediated DNA transfer have been developed, each of which has its advantages and disadvantages. Somatic cell nuclear transfer

\footnotetext{
* Corresponding Author: Yuyun Xing. Tel: +86-791-83813080, Fax: +86-791-83813080, E-mail: xingyuyun9@hotmail.com Submitted Jun. 10, 2015; Revised Sept. 23, 2015; Accepted Oct. 25, 2015
}

(SCNT) is one of the most extensively used techniques to obtain genetically modified domestic animals (Yang and Ross, 2012). More recently, a novel SCNT technique called handmade cloning (HMC), has been established to improve the efficiency of animal cloning (Vajta et al., 2004; Du et al., 2007; Zhang et al., 2012a). In the past 2-3 years, transcription activator-like effector nucleases and clustered regulatory interspaced short palindromic repeat (CRISPR)/Cas-based RNA-guided DNA endonucleases have become powerful tools in genome engineering (Gaj et al., 2013).

Transgenic technology has been applied in pigs (Prather 
et al., 2008) after the birth of the first transgenic livestock animal (Hammer et al., 1985). Since the pig is an excellent model for human medical and disease research, transgenic pigs have been generated to study disease related traits, such as clinical xenotransplantation (Cho et al., 2011; Yeom et al., 2012), pharmaceuticals (Watanabe et al., 2012), and models of human diseases (Renner et al., 2010; Yang et al., 2010; Sommer et al., 2011). In comparison, fewer studies focused on traits related to production (Hammer et al., 1985), meat quality (Lai et al., 2006) and low-phosphorus waste (Golovan et al., 2001).

Reproductive traits are economically important in the pig industry. However, only one transgenic study has been reported to improve pig reproductive traits (gilt follicular development). Guthrie et al. introduced human $\mathrm{Bcl}-2$ gene affecting follicular growth into the pig genome (Guthrie et al., 2005). Nevertheless, the transgenic gilts did not decrease the follicular atresia or increase ovulation rate. Bone morphogenetic protein receptor, type IB (BMPR1B) encodes a member of the bone morphogenetic protein receptor family of transmembrane serine/threonine kinases, which are involved in endochondral bone formation and embryogenesis. The $A 746 G(F e c B)$ mutation in $B M P R 1 B$ significantly affects the ovulation rate in Booroola-Merino sheep (Mulsant et al., 2001; Souza et al., 2001). The ewes with heterozygous and homozygous $F e c B$ mutation produced about 1.5 and 3.0 extra ova per oestrus, resulting in approximately 1.0 and 1.5 extra lambs, respectively (Davis, 2005). However, this causal mutation has not been found in mammals other than sheep and goat (Chu et al., 2010; Chu et al., 2011).

In this study, we constructed a vector containing the porcine BMPRIB CDS with the mutant allele $(G)$ at the $\mathrm{FecB}$ site by site-directed mutagenesis, and then introduced the vector into primary porcine fetal fibroblasts (PFF) by liposome-mediated transfection. Then we performed HMC to produce transgenic boars, with the aim to improve reproductive traits.

\section{MATERIALS AND METHODS}

\section{Ethics statement}

All procedures involving animals followed the guidelines for the care and use of experimental animals approved by the State Council of the People's Republic of China. The ethics committee of Jiangxi Agricultural University specifically approved this study.

\section{Detection of the BMPR1B A746G mutation in diverse pig breeds}

DNA samples of 20 pigs (10 females and 10 males) each from 3 Western breeds (Large White, Landrance, and Duroc), 11 Chinese local breeds (Bama Xiang, Baoshan
Big-Ear, Luchuan, Min, Jiaxin Black, Mingguang Small-Ear, Wuzhishan, Laiwu, Jinhua, Tibetan pig and Chinese wild boar) were used to genotype the BMPRIB A746G mutation. Genomic DNA was amplified with primers M-F (5'ATTGGAAAAGGTCGCTATGG-3') and M-R (5'CCAAAATGTTTTCATGCCTCA-3') at an annealing temperature of $59^{\circ} \mathrm{C}$. Polymerase chain reaction (PCR) products were visualized in $1.5 \%$ agarose gels, and the amplicons were directly sequenced on a 3130XL Genetic Analyzer (Applied Biosystems, Foster City, CA, USA).

\section{Construction of BMPR1B expression vector}

Total RNA was extracted from ovaries of healthy Large White sows using the TRIzol Reagent Kit (Invitrogen, Carlsbad, CA, USA) according to the manufacturer's instruction. cDNA was synthesized using the PrimeScriptRT reagent kit (TakaRa, Shiga, Japan). The synthesized cDNA was used as template to amplify the porcine BMPR1B coding region using the gene-specific primers CDS-F1 and CDS-R1 (Table 1), which were designed based on the mRNA sequence of porcine $B M P R 1 B$ gene (GenBank accession no. NM_001039745). To connect the isolated porcine BMPRIB CDS with pEF-GFP vector (a gift of Dr. Hongsheng Ouyang at Jilin University), two specific primers, EcoRI-F and NotI-R (Table 1), were designed to amplify the above-mentioned PCR products. The resulting amplicon was then cloned into pMD19-T using the TA cloning kit (TakaRa, Japan) and transformed into Escherichia coli (E. coli) DH5a competent cells (TakaRa, Japan). The bacteria liquid was used as template for overlap PCR with primers M-F1, M-R1, M-F2, and MR2 (Table 1) to introduce the BMPR1B A746G mutation. The purified PCR product was cloned into pMD19-T (TakaRa, Japan) and transformed into E. coli DH5a competent cells (TakaRa, Japan) again. Then the porcine $B M P R 1 B$ CDS with the introduced $A 746 G$ mutation was inserted into the pEF-GFP vector containing human EF1 $\alpha$ promoter using T4 DNA polymerase after digestion by $E c o R$ I and Not I, resulting in the pEF-BMPR1B vector. At the final step, PL452 (a gift from Dr. Hongsheng Ouyang at Jilin University) containing $\mathrm{Neo}$ was digested by EcoR I and Not I and blunt-ended using Hind III and Xba I, and pEF-BMPRIB was digested by Hind III and blunt-ended with T4 DNA polymerase. Both digested fragments of PL452 and pEF-BMPRIB were then ligated using T4 DNA polymerase to construct the final vector of $7.7 \mathrm{~kb}$, pEF$B M P R 1 B$-Neo (Figure 2A). The thermal cycling conditions of the PCRs for vector construction were all set as follows: $94^{\circ} \mathrm{C}$ for $5 \mathrm{~min}, 35$ cycles of $94^{\circ} \mathrm{C}$ for $30 \mathrm{~s}, 59^{\circ} \mathrm{C}$ to $61^{\circ} \mathrm{C}$ (Table 1) for $30 \mathrm{~s}$ and $72^{\circ} \mathrm{C}$ for 1 to $2 \mathrm{~min}$, and followed by a final extension for $5 \mathrm{~min}$ at $72^{\circ} \mathrm{C}$. To verify the successful introduction of the BMPR1B A746G mutation and the integrity of the transgene vector, plasmid DNA was directly 
Table 1. Polymerase chain reaction (PCR) primers used in this study

\begin{tabular}{|c|c|c|c|c|}
\hline Primer & Sequence (5'-3') & $\begin{array}{c}\text { Annealing } \\
\text { temperature }\left({ }^{\circ} \mathrm{C}\right)\end{array}$ & $\begin{array}{l}\text { Amplicon } \\
\text { (bp) }\end{array}$ & $\begin{array}{l}\text { Enzyme } \\
\text { (TaKaRa) }\end{array}$ \\
\hline \multicolumn{5}{|c|}{ Primers for construction of the vector } \\
\hline CDS-F1 & AAAGGAGCAAGCCTGCCATAC & 61 & 1,607 & rTaq \\
\hline CDS-R1 & ACCAACGAGTATCTACCGGCTT & & & \\
\hline EcoRI-F & ${\text { GATTCCAGGAATTCgccacc } A T G \text { CTT }^{1}}^{1}$ & 60 & 1,544 & rTaq \\
\hline NotI-R & CGATACCGCGGCCGCTCAGAGTTTAATGTC ${ }^{2}$ & & & \\
\hline M-F1 & CCAGAAGCTTGCCACCATG & 59 & 779 & rTaq \\
\hline M-R1 & GCCTCATCAACACTGTCGGATAT & & & \\
\hline M-F2 & GAGACAGAAATATATCGGACAGTG & 59 & 790 & rTaq \\
\hline M-R2 & TACCGCGGCCGCTCAGAGTTTAATG & & & \\
\hline \multicolumn{5}{|c|}{ Primers for characterization of the transgene vector sequence in the host genome ${ }^{3}$} \\
\hline L1-F & GCCACCTTCTACTCCTCCCCTAGTCAG & 68 & 6240 & La Taq \\
\hline L1-R & AGGGTGGTGGACTTCAGGTAATCATAGAG & & & \\
\hline L2-F & GCCACCTTCTACTCCTCCCCTAGTCAG & 68 & $5,475 / 7,006$ & La Taq \\
\hline L2-R & TCCTTTATTAGCCAGAAGTCAGATGCTCA & & & \\
\hline $\mathrm{N} 1-\mathrm{F}$ & CCTCGCACACATTCCACAT & 58 & 3,793 & La Taq \\
\hline N1-R & CGCCGCATACACTATTCTCA & & & \\
\hline $\mathrm{N} 2-\mathrm{F}$ & TCAAGCCTCAGACAGTGGTTC & 62 & 873 & La Taq \\
\hline $\mathrm{N} 2-\mathrm{R}$ & GTCCCTTTGATGTCTGCAGC & & & \\
\hline N3-F & GGCTATTCGGCTATGACTGG & 61 & 821 & rTaq \\
\hline $\mathrm{N} 3-\mathrm{R}$ & GGAGGGGCAAACAACAGAT & & & \\
\hline \multicolumn{5}{|c|}{ Primers for determination of transgene copy number } \\
\hline GAPDH-F1 & GGCTCTTTCTTTCCTTTCGC & 60 & 369 & rTaq \\
\hline GAPDH-R1 & $\begin{array}{l}\text { GATGCCTGCTTGCCGAATAGGATGCTCTAGGGTT } \\
\text { AGTTTGCT }\end{array}$ & & & \\
\hline NEO-F1 & $\begin{array}{l}\text { AGCAAACTAACCCTAGAGCATCCTATTCGGCAA } \\
\text { GCAGGCATC }\end{array}$ & 60 & 538 & rTaq \\
\hline NEO-R1 & GAGAGGCTATTCGGCTATGAC & & & \\
\hline GAPDH-F2 & ATGAATGAACCGCCGTTAGG & 60 & 66 & Premix ExTaq \\
\hline GAPDH-R2 & AGTCATGGGCAAGTAAGGAGAAAG & & & \\
\hline GAPDH-PRO & FAM-AATCTTCCTGAGTCCTTCA-MGB & & & \\
\hline NEO-F2 & CGGCACTTCGCCCAATAG & 60 & 57 & Premix ExTaq \\
\hline NEO-R2 & GTGCTCGACGTTGTCACTGAA & & & \\
\hline NEO-PRO & FAM-CCAGTCCCTTCCC-MGB & & & \\
\hline
\end{tabular}

sequenced on the $3130 \mathrm{XL}$ Genetic Analyzer (Applied Biosystem, USA) after linearization by Nhe I enzyme.

\section{Introduction of the mutated BMPR1B gene into porcine fetal fibroblasts}

PFF cells were cultured from Large White (USA) fetuses at 30 days of gestation. Cells were grown in Dulbecco's modified Eagle's medium (GIBCO, Grand Island, NY, USA) supplemented with $20 \%$ fetal bovine serum (FBS), 1\% non-essential amino acids, 1\% essential amino acids, $1 \mathrm{mM}$ sodium pyruvate, $100 \mathrm{IU} / \mathrm{mL}$ penicillin and $100 \mathrm{IU} / \mathrm{mL}$ streptomycin at $38.5^{\circ} \mathrm{C}$ in a humidified atmosphere of $5 \% \mathrm{CO}_{2}$ and $100 \%$ air. The $A 746 G$ mutation was first screened for the PFF cells by PCR using primers
M-F and M-R, and the PCR products were directly sequenced on the 3130XL Genetic Analyzer (Applied Biosystem, USA). PFF cells were then sex determined by PCR using primers 5'-CCGACGGACAATCATAGC-3' and 5' -GGTGGATGT TACCCTACTGT- 3' with the following conditions: $95^{\circ} \mathrm{C}$ for $5 \mathrm{~min}, 30$ cycles of $\left(94^{\circ} \mathrm{C}\right.$ for $20 \mathrm{~s}$, $60^{\circ} \mathrm{C}$ for $20 \mathrm{~s}$ and $72^{\circ} \mathrm{C}$ for $45 \mathrm{~s}$ ), followed by a final extension for $5 \mathrm{~min}$ at $72^{\circ} \mathrm{C}$. The masculine PFF cells were transfected with the pEF-BMPRIB-NEO vector using liposome reagents (FUGene HD; Roche, Basel, Switzerland) at a FUGeneHD $(\mu \mathrm{L})$ to linearized vector DNA $(\mu \mathrm{g})$ ratio of $3: 1$ according to the manufacturer's protocol. Three days after transfection, the cells were cultured in selection medium containing $400 \mu \mathrm{g} / \mathrm{mL}$ of 
Geneticin (G418; Sigma, St. Louis, MO, USA) for 2 weeks with medium changed every other day. The G418-resistant colonies were then picked and propagated.

Polymerase chain reaction analysis of transgenic cell lines

Genomic DNA of the picked colonies was extracted using the OMEGA Tissue DNA kit (Bio-Tek, Norcross, GA, USA) according to the manufacturer's instruction. The DNA was used to amplify the vector region spanning the promoter and BMPR1B CDS using N2-F and N2-R primers (Table 1). PCR conditions were an initiation of $94^{\circ} \mathrm{C}$ for 5 min, 35 cycles of $94^{\circ} \mathrm{C}$ for $30 \mathrm{~s}, 62^{\circ} \mathrm{C}$ for $30 \mathrm{~s}$, and $72^{\circ} \mathrm{C}$ for $30 \mathrm{~s}$, followed by an extension at $72^{\circ} \mathrm{C}$ for $10 \mathrm{~min}$.

\section{HMC and culture of reconstructed embryos}

Cumulus-oocyte complexes (COCs) were collected from slaughter house-derived sow ovaries and matured in bicarbonate-buffered TCM-199 (GIBCO, USA) supplemented with $10 \%(\mathrm{v} / \mathrm{v}) \mathrm{FBS}, 10 \%(\mathrm{v} / \mathrm{v})$ pig follicular fluid, $5 \mathrm{IU} / \mathrm{mL}$ human chorionic gonadotropin and 10 $\mathrm{IU} / \mathrm{mL}$ equine chorionic gonadotropin at $38.5^{\circ} \mathrm{C}$ in $100 \%$ humidified atmosphere of $5 \% \mathrm{CO}_{2}$ for 42 to $44 \mathrm{~h}$.

The HMC was performed as described previously (Vajta et al., 2004; Du et al., 2007; Zhang et al., 2012a). Briefly, cumulus cells were removed from matured COCs using 1 $\mathrm{mg} / \mathrm{mL}$ hyaluronidase in HEPES-buffered TCM-199. After partial digestion of zona pellucida, oocytes were enucleated by oriented bisection with an ultra-sharp microblade $(\mathrm{AB}$ Technology, Pullman, WA, USA). Fusion was performed in two steps. First, each cytoplast without polar body was dropped over a single transgenic fibroblast and fused in fusion medium containing $0.3 \mathrm{M}$ mannitol, $0.1 \mathrm{mM} \mathrm{MgSO}_{4}$ and $0.01 \%(\mathrm{w} / \mathrm{v})$ polyvinyl alcohol in a 450 fusion chamber (BTX, San Diego, CA, USA) by a single direct current impulse of $2.0 \mathrm{kV} / \mathrm{cm}$ for $9 \mu \mathrm{s}$; secondly, each cytoplastsomatic cell pair was activated with another cytoplast in specific medium (fusion medium with $0.1 \mathrm{mM} \mathrm{CaCl}_{2}$ ) using a single direct current impulse of $0.86 \mathrm{kV} / \mathrm{cm}$ for $80 \mu \mathrm{s}$.

The reconstructed embryos were incubated in porcine zygote medium 3 with the addition of $5 \mu \mathrm{g} / \mathrm{mL}$ cytochalasin $\mathrm{B}$ and $10 \mu \mathrm{g} / \mathrm{mL}$ cyclohexinmide for $4 \mathrm{~h}$, and then cultured in PZM-3 supplemented with $4 \mathrm{mg} / \mathrm{mL}$ FBS at $38.5^{\circ} \mathrm{C}$ in $5 \% \mathrm{CO}_{2}, 5 \% \mathrm{O}_{2}, 90 \% \mathrm{~N}_{2}$, and $100 \%$ humidity for 5 to 6 days. About one hundred blastocysts at day 5 or 6 with good morphology were surgically transplanted to each of 8 recipient sows (embryos were transferred into the uterine horns) at 5 or 6 days of standing estrus. Pregnancies were detected by a B-mode ultrasonography machine at 30 days after the surgery.

\section{Polymerase chain reaction screening of transgenic piglets}

To check the integrity of the exogenous gene in the cloned transgenic pigs, genomic DNA was extracted from ear tissues of 12 survived boars using standard phenol/chloroform method. DNA quality was detected by a Nanodrop-100 spectrophotometer (Thermo Fisher, Waltham, MA, USA). Fragments of two long PCR and three conventional ones were obtained by amplification of genomic DNA using primers listed in Table 1. DNA of 6 donor cell lines were set for those PCR as well. The amplicons overlapped and covered the entire region of the transgenic vector. PCR products were checked by electrophoresis in $0.8 \%$ to $1.5 \%$ gels and then directly sequenced on the 3130XL Genetic Analyzer (Applied Biosystem, USA). To distinguish the transgene-positive and negative $F_{1}$ pigs, long PCR was performed to amplify the genomic DNA from these individuals using primers L1-F and L1-R (Table 1). Genomic DNA of $F_{1}$ offspring was extracted from ear tissues using standard phenol/chloroform method as well.

\section{Genome walking analysis}

After PCR analyses of the 12 transgenic pigs, genome walking analysis was conducted to detect the flanking sequence of the exogenous gene of a boar with the highest vector integrity using the GenomeWalker Universal Kit (Clontech, Mountain View, CA, USA). The primers used for the primary and secondary PCR were 5'-TTGCTA GGAGATGCGTATCAGGAGGTA-3' and 5'-AGTAGC GACGAGTGTCTAAGGCAGATG-3', respectively. $P v u$ II restriction enzyme supplied by this kit was chosen to digest genomic DNA based on the vector sequence. The amplified fragments were separated by electrophoresis in $1.5 \%$ gels and then directly sequenced on the 3130XL Genetic Analyzer (Applied Biosystem, USA). Further long PCR with primers scanning the transgenic vector and flanking sequence were implemented to validate the insertion sites. The primers for confirming two insertion sites were: SSC12-FP (5'CGCTGTTCTCCTCTTCCTCATCTCC-3') and SSC12-RP (5'-AGGGCATTCTCAGTGTGTCTGT TCGT-3'); SSC13-FP (5'-GCCTTCTATCGCCTTCTTGAC GAGTTCTT-3') and SSC13-RP (5'-GTGCTGCTTCAGG TGTTCCTACTGGATTT-3'), respectively.

\section{Copy number assay of exogenous gene in transgenic animals}

$\mathrm{NeO}$ and GAPDH specific amplicons of 538 bp and 369 bp were generated by conventional PCR with primers NEOF1/R1 and GADPH-F1/R1 (Table 1), respectively. The two amplicons were linked to form GAPDH-NEO fragment (907 bp) by bridge PCR using primers GAPDH-F1 and NEO-R1 (Table 1). The integrated fragment was cloned into a pGEM-T Easy vector (Promega, Madison, WI, USA) and then sequenced on the 3130XL Genetic Analyzer (Applied Biosystem, USA) to verify the identity. 
TaqMan probes and primers (Table 1) were designed for quantitative PCR (qPCR) of target (Neo) and reference $(G A P D H)$ genes. Both probes were minor groove binder (MGB) ones with carboxyfluorescein (FAM) report label. The amplification of these two genes were detected by absolute quantification. A standard curve was generated using a ten-fold serial dilution of recombinant $G A P D H$ $N E O$ plasmid. qPCR assay was performed for transgenic founder pigs and $F_{1}$ offspring produced by No. 11 boar using the premix EX Taq Kit (TakaRa, Japan). The qPCR conditions were $50^{\circ} \mathrm{C}$ for $2 \mathrm{~min}, 95^{\circ} \mathrm{C}$ for $10 \mathrm{~min}$, and 40 cycles of $94^{\circ} \mathrm{C}$ for $15 \mathrm{~s}$ and $60^{\circ} \mathrm{C}$ for $1 \mathrm{~min}$. Each sample was analyzed in triplicate. The results were expressed as a fold ratio of the normalized target amounts to the reference amounts.

\section{Analysis of $B M P R 1 B$ expression in $F_{1}$ piglets}

Boar No. 11, which had the entire exogenous promoter and CDS, was chosen to cross with non-transgenic Large White sows (Canada). Two transgene-positive and two negative $F_{1}$ female siblings were slaughtered at 3 days of age to collect tissues for expression analyses of the $B M P R 1 B$ gene.

Total RNA was extracted using the TRIzol Reagent kit (Invitrogen, USA), and cDNA was synthesized using the PrimeScriptRT reagent kit (TaKaRa, Japan). The cDNA templates were used to amplify the $A 746 G$ mutation with primers M-F and M-R (Table 1). The PCR condition was the same as that for the vector construction. PCR products were cloned to pGEM-T vector (Promega, USA) and then used for blue-white colony screening. PCR products were directly sequenced on the 3130XL Genetic Analyzer (Applied Biosystem, USA).

Total protein was extracted from tissues using a Total Protein Extraction Kit (Applygen, Beijing, China). Approximate $40 \mu \mathrm{g}$ protein of each sample was loaded on a discontinuous sodium dodecyl sulfate polyacrylamide gel electrophoresis gel. The samples were run at $80 \mathrm{~V}$ for 20 min in stacking gels (5\%) and at $120 \mathrm{~V}$ for $40 \mathrm{~min}$ in resolving gels $(8 \%)$. The separated polypeptides were transferred from the slab gels to $0.45 \mu \mathrm{m}$ polyvinylidene fluoride membrane (Millipore, Billerica, MA, USA) at 35 $\mathrm{mA}$ for $3 \mathrm{~h}$ in transfer buffer $(38.63 \mathrm{mM}$ glycine, $250 \mathrm{mM}$ Tris, $1 \mathrm{~g} / \mathrm{L}$ SDS, $20 \%$ methanol). The blotted membrane was blocked with 5\% skim milk in tris-buffered saline with Tween 20 (TBST) (150 mM NaCl, 10 M Tris-HCl pH 8.0, $1 \%$ Tween-20) for overnight at $4{ }^{\circ} \mathrm{C}$. After washing the membrane with TBST for 3 times, BMPR1B antibody (Santa Cruz Biotechnology, Santa Cruz, CA, USA) diluted in TBST $(1: 5,000)$ was added and incubated for $3 \mathrm{~h}$ at room temperature. The bound antibodies were detected using horseradish peroxidase conjugated goat anti-rabbit immunoglobulins (ZSGB-BIO, Beijing, China) at dilution 1:5,000 in TBST as secondary antibody. Beta actin was used as loading control. The anti-beta actin antibody (Abcam, Cambridge, UK) and Peroxidase-Conjugates AffiniPure Goat Anti-Mouse IgG (H+L) (ZSGB-BIO, China) were used as primary and secondary antibodies accordingly. The bands were visualized with the ECL Chemiluminescent kit (Transgen, Beijing, China) and scanned with GeneSnap software on a GeneGnome Scanner (Syngene, Cambridge, UK). Band intensities were quantified using GeneTools software (Syngene, UK). The relative amount of BMPR1B was calculated after correction for the amount of $\beta$-actin.

\section{Reproductive trait analyses}

Boar No. 11 was mated to 7 wild-type Large White (Canada) sows to produce 1 to 2 litters each. Three transgene-positive $F_{1}$ boars were further selected to cross with $F_{1}$ sows. $F_{1}$ sows from the same litter, either positive or negative, were mated with the same boar avoiding full-sib mating. Reproductive performances, including the total number of piglets born (TNB), the number of piglets born alive (NBA), the number of weak piglets (NW), the number of mummies (NM) and the number of still-born (NSB), were recorded.

Semen collection and quality assessment of transgenepositive and negative $F_{1}$ boars were performed as described previously (Xing et al., 2009). Briefly, boars were trained 15 to 30 min per day to mount and mate dummy sow from 280 days of age. After two successful matings, semen of each boar was collected for quality assessment by glovehand method 4 times at an interval of 4 days. Sperm motility was detected with a light microscope at $200 \times$ magnification immediately after semen collection. Semen volume of each ejaculation was determined using a graduated cylinder. Sperm concentration was measured with haemocytometer slides after diluting semen samples with $3 \% \mathrm{NaCl}$ solution. The total sperm number per ejaculate was calculated by multiplying the semen volume by the sperm concentration. Six transgene-positive and 6 negative boars from three litters with good health conditions were selected for semen collection blind-labeled. The R language was used to perform the t-test statistical analysis.

\section{RESULTS}

Detection of the BMPR1B $A 746 G$ mutation and the transgene vector in swine and porcine fetal fibroblasts

In this study, the $G$ allele of the BMPR1B $A 746 G$ mutation site was absent in all tested animals $(\mathrm{n}=280)$ representing 3 Western commercial breeds and 11 Chinese local breeds. All individuals were $A A$ homozygotes. PFF 


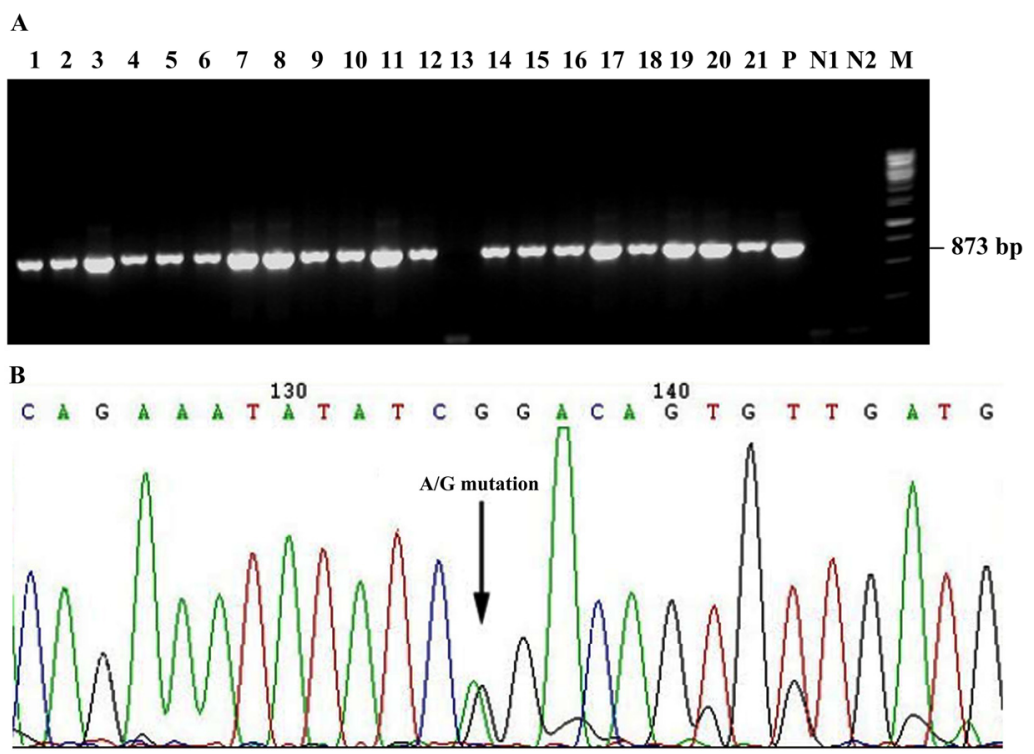

Figure 1. Identification of transgenic donor cells. (A) Detection of the transgenic cells. Lanes 1 to 21 indicate the amplification results of different geneticin-resistant cell clones. P, transgenic plasmid DNA; N1, water; N2, untransfected porcine fetal fibroblasts. M indicates 1 kb DNA Ladder. (B) Sequencing result from polymerase chain reaction product of one transgenic donor cell line. The arrow indicates the introduced mutation site.

cells for transfection were also screened and $G G$ and $G A$ genotypes were not found. Direct sequencing analysis showed that the transgene vector has a size of $7.7 \mathrm{~kb}$ containing the 1,509 bp BMPRIB CDS with the introduced $G$ allele and complete sequence of promoter, rabbit globin polyA terminator and neo regions.

\section{Screening of the transgenic cells}

A total of 91 clones were picked and genotyped via PCR-sequencing. Promoter and CDS were successfully amplified in 73 of the 91 clones (data not shown), indicating that the majority of G418 geneticin-resistant cell clones were transgenic (Figure 1A). In addition, we confirmed the existence of the induced BMPR1B $A 746 G$ mutation in the host genome by sequencing of the clones (Figure 1B).

\section{Transgenic pigs produced by handmade cloning}

Thirty days after the embryo transfer, 7 out of 8 recipients were confirmed to be pregnant with B-mode ultrasonographic examination. A total of 24 piglets were obtained from 5 recipient sows after 112 to 116 days gestation (Table 2). One of these recipients gave birth by Cesarean section and four piglets were born dead. Of these 20 naturally born piglets, 12 survived to maturity, and the others died mostly of diarrhea before weaning. The birth weight of the 24 cloned transgenic piglets ranged from 0.60 to $1.50 \mathrm{~kg}$, with a mean of $0.99 \mathrm{~kg}$. The average weight of the surviving 12 piglets was $1.03 \mathrm{~kg}$ in average, ranging from 0.70 to $1.50 \mathrm{~kg}$.

\section{Identification of cloned transgenic pigs}

To detect the integrity of the exogenous transgenic vector in the 12 matured cloned pigs, we performed two

Table 2. Production of cloned transgenic pigs

\begin{tabular}{|c|c|c|c|c|c|c|c|}
\hline Recipient sows ID & $\begin{array}{l}\text { No. of transferred } \\
\text { blastocysts }\end{array}$ & Pregnancy & Cell lines ${ }^{1}$ & $\begin{array}{l}\text { Gestation } \\
\text { (d) }\end{array}$ & Born piglets & $\begin{array}{c}\text { Number born } \\
\text { alive }\end{array}$ & $\begin{array}{l}\text { Boars till } \\
\text { maturation }\end{array}$ \\
\hline 1 & 94 & Yes (Abortion) & $\mathrm{C} 1$ & - & - & - & - \\
\hline 2 & 84 & Yes & $\mathrm{C} 3$ & 116 & 4 & 4 & No.11 \\
\hline 3 & 94 & Yes (Abortion) & $\mathrm{C} 3$ & - & - & - & - \\
\hline 4 & 84 & Yes & $\mathrm{C} 1$ & 110 & 2 & 2 & No.1, 2 \\
\hline 5 & 121 & No & $\mathrm{C} 1 / \mathrm{C} 4$ & - & - & - & - \\
\hline 6 & 110 & Yes & $\begin{array}{c}\mathrm{C} 1 / \mathrm{C} 2 / \mathrm{C} 3 / \\
\mathrm{C} 4 / \mathrm{C} 6\end{array}$ & 112 & 8 & 8 & $\begin{array}{c}\text { No. } 6,7,8,9, \\
10,12\end{array}$ \\
\hline 7 & 87 & Yes & $\mathrm{C} 1 / \mathrm{C} 4 / \mathrm{C} 5$ & 113 & 6 & 6 & No. $3,4,5$ \\
\hline 8 & 104 & Yes & $\mathrm{C} 1 / \mathrm{C} 2 / \mathrm{C} 4$ & 114 & $4^{2}$ & 0 & - \\
\hline
\end{tabular}

\footnotetext{
${ }^{1}$ These cell lines were selected from 91 clones.
}

${ }^{2}$ The four piglets were obtained by Caesarean section and all of them were dead at birth. 
long-PCR using the primers spanning the majority of the vector. The result of first long-PCR indicated that only No. 11 had the vector spanning the beginning of vector and the majority of the CDS (Figure 2B). The second long-PCR using primers spanning the whole vector showed that only No. 12 had a fragment, smaller in size than the expected length (Figure 2C). Then we implemented two conventional PCRs, one spanned the front part of the vector (Figure 2D) and the other spanned the pivotal promoter and CDS regions (Figure 2E). The former PCR showed that all except No. 6 were transgene-positive (Figure 2D), and the latter PCR (Figure 2E) together with the long PCRs (Figure 2B and $2 \mathrm{C}$ ) revealed that only No. 11 had the full promoter and CDS regions but lacked part of the terminator. We further designed an extra pair of primers spanning the Neo region, and the PCR confirmed that No. 6 was transgene-negative (Figure 2F). In the above-mentioned five PCRs, DNA of 6 donor cell lines served as control. All had the expected

A

\begin{tabular}{|c|c|c|c|c|c|}
\hline $\overrightarrow{\mathrm{B}-\mathrm{f}} / \mathrm{C}-\mathrm{r}$ & & & & 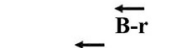 & $\overleftarrow{\mathrm{C}-\mathrm{r}}$ \\
\hline PL452, & PL452 & PEF & $\overrightarrow{\mathbf{E}-\mathrm{f}}$ & $\overleftarrow{\mathrm{E}-\mathrm{r}}$ & PL45 \\
\hline
\end{tabular}

B Primer pair: B-f/B-r

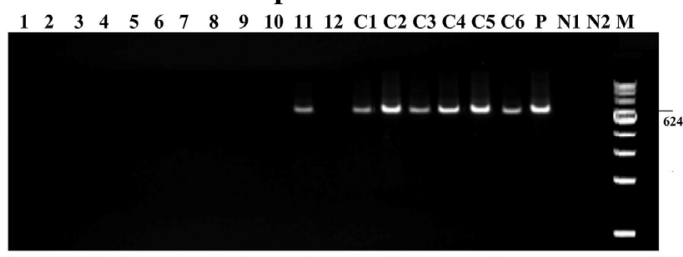

C Primer pair: C-f/C-r

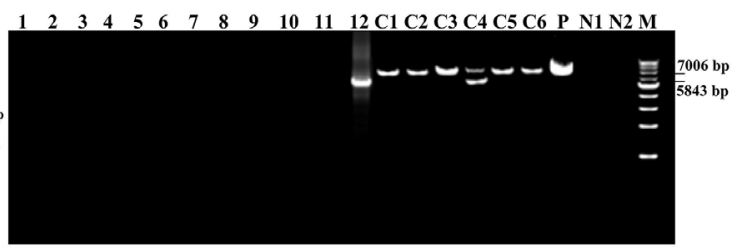

D

Primer pair: D-f/D-r

E Primer pair: E-f/E-r
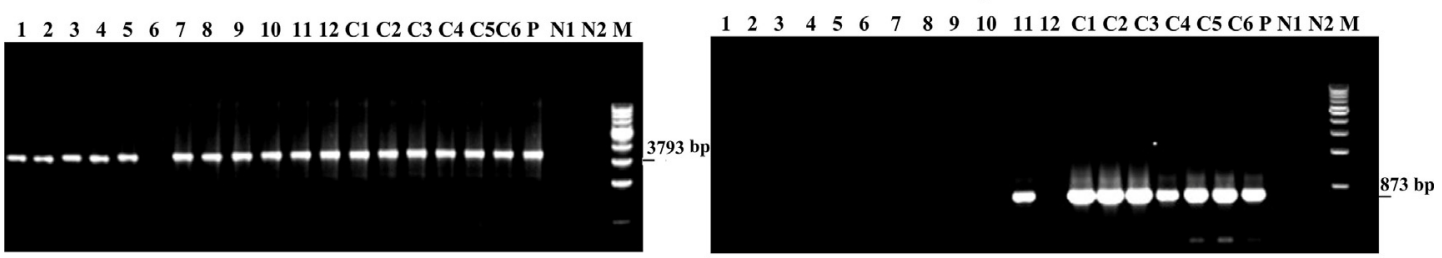

F

Primer pair: F-f/F-r

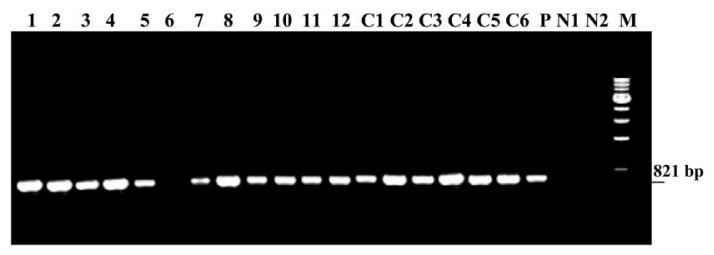

G

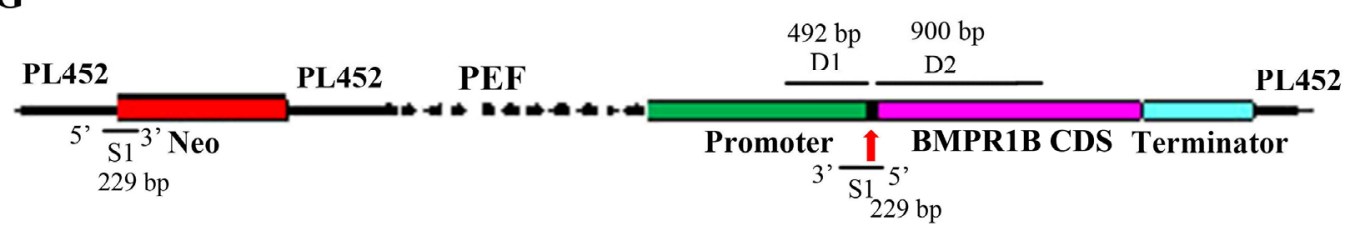

Figure 2. Polymerase chain reaction (PCR) detection of cloned transgenic pigs. (A) Diagrammatic representation of the $\mathrm{pEF}-B M P R 1 B-$ Neo transgenic vector and PCR primer design. B, C, D, E, and F indicate positions of primers. Primers B, C, D, E, and F are identical to the L1, L2, N1, N2, and N3 in Table 2. The $\mathrm{f}$ and $\mathrm{r}$ denote the primer orientations (forward and reverse). PL452 and PEF indicate the backbones of pEF-GFP and PL452 vectors used in this study. (B-F) PCR analyses of cloned transgenic pigs and donor cell lines. Lanes 112, PCR products of the 12 cloned transgenic pigs; C1-C6, PCR products of donor cell lines; P, N1, and N2 represent the transgenic plasmid DNA, water and DNA of non-transgenic pig, respectively. M, 1 kb DNA Ladder. (G) Sequence analysis of PCR products from pig No. 12 and 5,843 bp fragment of $\mathrm{C} 4$ cell line in (C). D, deletion; S1, insertion fragment. The arrow indicates the insertion site. 
fragments of right sizes (Figure $2 \mathrm{~B}$ to $2 \mathrm{~F}$ ). An extra band showed up in $\mathrm{C} 4$ cell line in PCR, and it had the same size as that for pig No. 12 (Figure $2 \mathrm{C}$ ). To verify the identity of exogenous vector in those 12 pigs and 6 donor cell lines, all PCR products were purified and directly sequenced. The data (not shown) indicated that the smaller fragment $(5,843$ bp) from $\mathrm{C} 4$ had the same sequence as that of No. 12. All other fragments were identical to the plasmid DNA. Sequencing data for No. 12 revealed that 2 deletions and 1 conversed insertion happened to the transgenic vector in these two products. The two deleted segments were located in the promoter and the CDS, with fragment sizes of $492 \mathrm{bp}$ and $900 \mathrm{bp}$, respectively. The inserted segment of $229 \mathrm{bp}$ was located between the promoter and the CDS (Figure 2G). Combining the PCRs and sequencing results, we concluded that all except one (No. 6) cloned pigs were transgenepositive. However, none of the 11 transgene-positive pigs had the intact exogenous vector, and 10 of them lost part or whole promoter and CDS regions. With regard to donor cell lines, the $\mathrm{C} 4$ cell line contained at least two clone populations, one had an intact transgene cassette and the other carried rearrangements.

\section{Transgenic insertion site of pig No. 11}

By applying genome walking analysis, we detected two insertion sites for the transgenic vector in No. 11 pig (Figure 3). One insertion site was located within exon 6 of the NAGLU gene at $20,485,379$ bp on pig chromosome (SSC) 12 (Sscrofa 10.2) (Figure 3A). The other site was located within intron 1 of the CMTM8 gene at 20,503,293 bp of SSC 13 (Figure 3B). Further PCR spanning the beginning of vector and the 3 ' flanking sequence verified these two insertion sites, and the fragment sequences showed that the full vector sequences were inserted into the host genome (Figure 3C) except the lost part of the terminator sequence (Figure $3 \mathrm{~A}$ and $3 \mathrm{~B}$ ).

\section{Detection of the copy numbers of the exogenous gene}

qPCR revealed that all founder pigs except for pig No. 6 had 1 to 2 copies of the Neo gene (Figure 4A), confirming that pig No. 6 was a transgenic negative individual. Of the 11 transgene-positive pigs, No. 4, 9, and 12 had one copy and the rest had two copies of Neo. The copy number of pig No. 11 (two copies) was concordant with the genome walking analysis of this individual. In addition, the $F_{1}$ pigs

$\mathbf{A}$

Secondary primer for genome walking

AGTAGCGACGAGTGTCTAAGGCAGATGGGGAAACTCATGACAGAATGCTGGGCGCAGAATCCTG CCTCCAGACTGACAGCCCTGCGGGTGAAGAAAGCACTGGCCAAGATGTCAGAGTCCAGGACATT

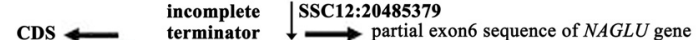
AAACTCTGAgeggegeactecteagCTGGCA GGACTG GTGGCTGACTACTACACCCCCCGCTGGCGGCTCTTCA TGGAGATGCTGGTTGAAAGCCTGGTCCAAGGCATCCCCTTCCAACAGCACCAGTTTGACCAGAACGTCTTCCAG

Secondary primer for genome walking AGTAGCGACGAGTGTCTAAGGCAGATGGGGAAACTCATGACAGAATGCTGGGCGCAGAATCCTG CCICCAGACTGACAGCCCTGCGGGTGAGAAAACACTGGCCAAGATGCAGAGTCCCAGGACATI incomplete |SSC13:20503293 AAACTCTGA geggecgcactcetcag CTGAAACACAACATTGTAAATCAACTACATTCCAATGTAAAATTTTTAAAAA GAGTAAAAAAAAAGTAGAGAACAATTTTCCTAAAATCAGCTAAAATCACTTTTTACACTAGCTCATAATTGGGGG GGGGTAATCTTTGCCCAGTGGCTGGAACCCAAATCTTCCAGAAAAACAACCATTTTTTGAGAGCAAACACATGG GGGATGAGTTGAAAAGGCACCCTCATGAGGCTATTAAAATAATGAAAACCTGGACAGAAGTTGGGCTGCTCTGC TGCCCTCTACTGGCAGGGTCAAGGATCAACAACACACAAAGTGCCCAAGTGGGCACACACCCCTCTGTTCCTCT GTGGCTGGGTCATGTCCTACTCCTCCTGAGAAAAACCTGGGTGAGAAAAGCAGGGGCTTCAACCCATGGAACC TCAAATCCAGTAGGAACACACCAGCCCGGGCCGTCGACCACGCGTGCCCT

C

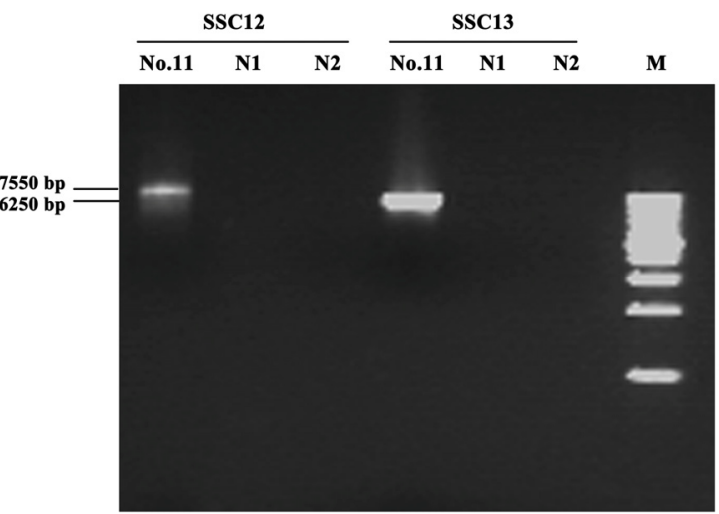

Figure 3. The integration sites of the transgenic vector of No. 11 boar. (A) The integration site on SSC12. (B) The integration site on SSC13. The vertical arrows indicate the insertion site. (C) Polymerase chain reaction verification of two integration sites of pig No. 11. N1 and N2 represent the DNA of non-transgenic pig and water, respectively. M indicates 1 kb DNA Ladder Marker. 
A

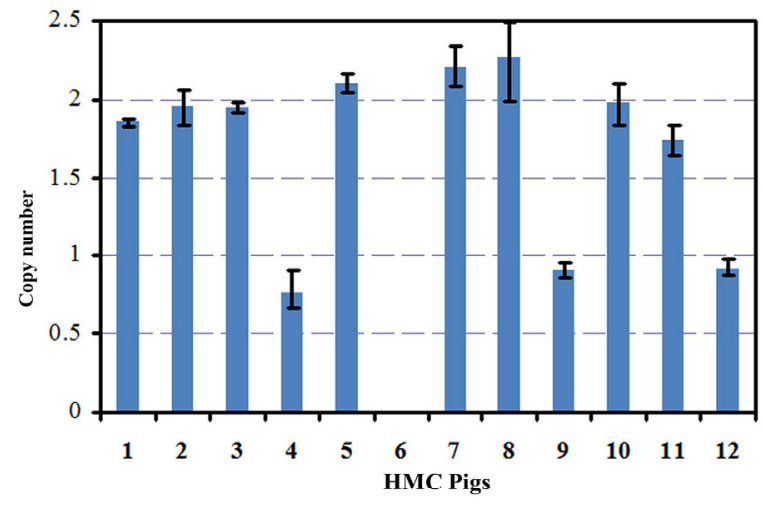

B

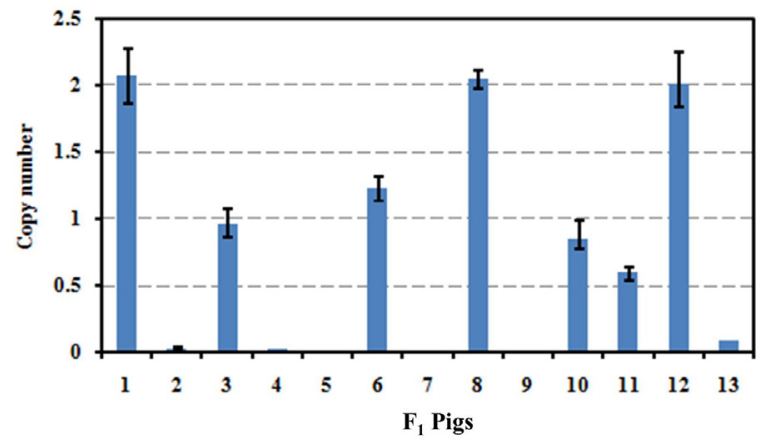

Figure 4. Copy number of exogenous $\mathrm{Neo}$ in transgenic pigs. (A) 12 cloned transgenic pigs and (B) a litter of $F_{1}$ pigs produced by No. 11 founder boar determined by quantitative polymerase chain reaction. Standard deviation bars are shown.

generated from No. 11 boar had 0,1 , or 2 copy numbers of the exogenous gene (Figure 4B).

\section{Detection of the expression of the BMPR1B gene}

Blue-white screening of cDNA of $\mathrm{F}_{1}$ positive piglets revealed that the introduced mutant allele (746G) was expressed in brain, cerebellum, liver, lung, spleen, small intestine, skeletal muscle and ovary but not in stomach and bladder. In comparison, the wild-type allele (746A) was found in all 10 tissues (Figure S1).

Western blotting results showed that the BMPR1B protein expression levels in the spleen, muscle, kidney, lung,
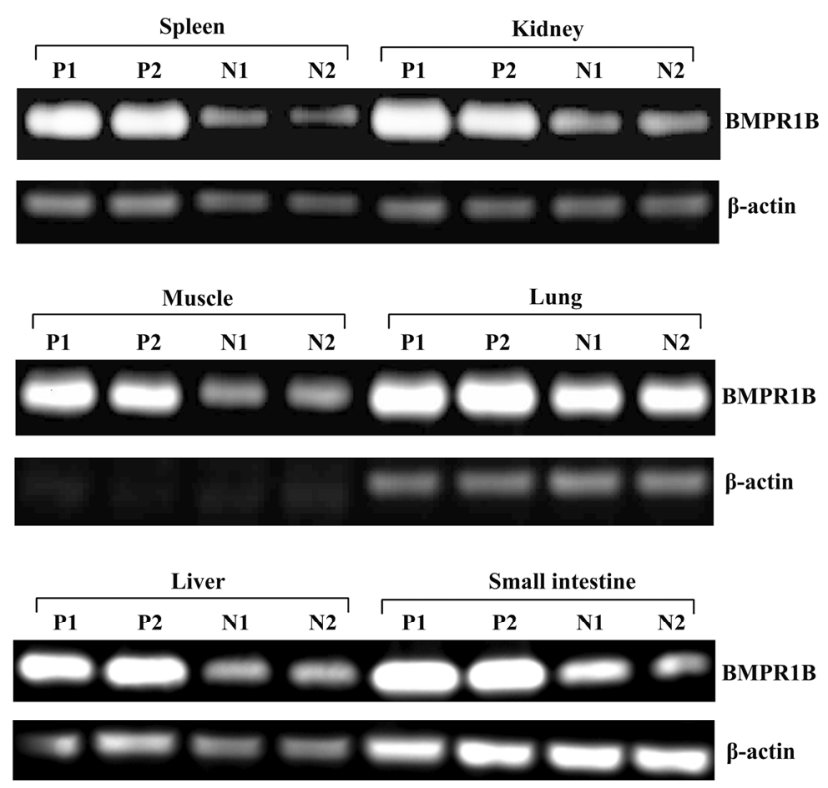

Figure 5. Western blot analysis of BMPR1B in multiple tissues from $F_{1}$ piglets. $\mathrm{P} 1$ and $\mathrm{P} 2$, transgene-positive pigs, $\mathrm{N} 1$ and $\mathrm{N} 2$, transgene-negative pigs.

liver and small intestine samples of transgene-positive piglets were $1.25,1,1,0.5,1$, and 2 times higher than those of transgenic negative piglets (Figure 5).

\section{Reproductive performance of transgenic pigs}

In this study, boar No. 11 was mated with 7 wild-type Large White sows and gave birth to 13 litters of $F_{1}$ pigs. These sows had an average of 12.77 TNB, 11.85 NBA, 0.77 $\mathrm{NW}, 0.31 \mathrm{NM}$, and $0.62 \mathrm{NSB}$, respectively (Table 3). Transgene-positive $F_{1}$ boars were selected to cross with transgene-positive and negative sows. The positive and negative $F_{1}$ sows had average 11.22 and $12.10 \mathrm{TBN}, 9.11$ and $10.20 \mathrm{NBA}, 0.33$ and $0.20 \mathrm{NW}, 0.11$, and $0.10 \mathrm{NM}$ and 2.00 and $1.80 \mathrm{NSB}$, respectively.

Regarding semen characteristics, transgene-positive boars had higher semen volume, sperm concentration and total sperm per ejaculate than negative ones, but the

Table 3. Litter size performance of transgenic pigs

\begin{tabular}{|c|c|c|c|c|c|c|}
\hline \multirow{3}{*}{ Traits } & \multirow{2}{*}{\multicolumn{2}{|c|}{$\mathrm{F}_{0}(\mathrm{~N}=13)$}} & \multicolumn{4}{|c|}{$\mathrm{F}_{1}$} \\
\hline & & & \multicolumn{2}{|c|}{ Transgene-positive $^{1}(\mathrm{~N}=9)$} & \multicolumn{2}{|c|}{ Transgene-negative $(\mathrm{N}=10)$} \\
\hline & Mean \pm SE & Range & Mean \pm SE & Range & Mean \pm SE & Range \\
\hline TNB & $12.77 \pm 0.85^{\mathrm{a}}$ & $10-22$ & $11.22 \pm 1.01^{\mathrm{a}}$ & $5-15$ & $12.10 \pm 0.90^{\mathrm{a}}$ & $6-15$ \\
\hline NBA & $11.85 \pm 0.77^{\mathrm{a}}$ & $9-20$ & $9.11 \pm 1.03^{\mathrm{a}}$ & $3-10$ & $10.20 \pm 1.01^{\mathrm{a}}$ & $4-14$ \\
\hline NW & $0.77 \pm 0.28^{\mathrm{a}}$ & $0-1$ & $0.33 \pm 0.24^{\mathrm{a}}$ & $0-2$ & $0.20 \pm 0.13^{\mathrm{a}}$ & $0-1$ \\
\hline NM & $0.31 \pm 0.17^{\mathrm{a}}$ & $0-2$ & $0.11 \pm 0.11^{\mathrm{a}}$ & $0-2$ & $0.10 \pm 0.10^{\mathrm{a}}$ & $0-1$ \\
\hline NSB & $0.62 \pm 0.31^{\mathrm{a}}$ & $0-4$ & $2.00 \pm 0.33^{\mathrm{b}}$ & $0-4$ & $1.80 \pm 0.65^{\mathrm{b}}$ & $0-4$ \\
\hline
\end{tabular}

$\mathrm{F}_{0}$, litter size performance of No. 11 boar and wild-type Large White sows; $F_{1}$, litter size performance of $F_{1}$ transgene-positive boars and $F_{1}$ sows; N, number of litters; SE, standard error; TNB, the total number of piglets born; NBA, the number of piglets born alive; NW, the number of weak piglets; $\mathrm{NM}$, the number of mummies; NSB, the number of still-born.

${ }^{1}$ Copy number detection revealed that 6 of 9 transgene-positive sows had both integration sites of exogenous vector (data not shown).

Different small letters in the same row indicate significant difference at 0.05 level. 
differences were not significant (Table 4). The most significant difference was found in semen volume (322.59 vs $288.55, p=0.06)$. These two boar groups had same mean value of sperm motility (Table 4).

\section{DISCUSSION}

In this study, we generated 24 cloned transgenic piglets by 5 recipient sows using the HMC technique (Table 2) and 12 survived until maturation. This work had a similar cloning efficiency compared with the previous study (Zhang et al., 2012a), who obtained 16 piglets from three recipients. Our study illustrated that the HMC technique is robust for the generation of cloned transgenic animals.

To detect the integrity of the exogenous transgenic vector in the 12 pigs that reached sexual maturity, we conducted a series of PCR analyses and found that only No. 11 had the entire promoter and the CDS regions. We then performed genome walking to detect the flanking sequences of the transgene cassette in No. 11 boar. Two integration sites were found, and both had the full promoter and CDS sequence and shortened terminator (Figure 3A, 3B, and 3C). This well explained that No. 11 had amplification products in the first long PCR (Figure 2B) but not in the second long PCR (Figure 2C) when detecting transgenic vector integrity. Further, we implemented absolute quantification analysis using primers spanning the $N E O$ region that existed in all transgene-positive pigs (Figure $2 \mathrm{D}$ and $2 \mathrm{~F}$ ). The results confirmed that No. 6 and No. 11 had 0 and 2 copies of the exogenous vector, respectively (Figure 4A). Moreover, the copy numbers of $\mathrm{Neo}$ in $\mathrm{F}_{1}$ pigs $(0,1$, or 2$)$ produced by No. 11 boar showed the stable inheritance of the exogenous gene (Figure 4A and 4B). High frequencies of transgenic aberrations such as deletion, duplication and rearrangement have been found in transgenic animals produced by microinjection (Mark et al., 1992; Chen et al., 1995; Nakanishi et al., 2002; Forsberg et al., 2013). In contrast, the transgene rearrangement seems to be greatly reduced either in the donor cells grown in culture or in the transgenic animals produced by SCNT (Atala et al., 2011). In our study, we selected donor cells under G418 and isolated clones that were identified positive by PCR using primers spanning promoter and CDS (Figure 1A). In PCR screening of 12 cloned transgenic pigs and 6 donor cell lines, C4 donor cell line was later found to be a mixed population. The other 5 cell lines showed expected unique
PCR products. However, none of the transgene-positive pigs had the full transgenic vector, suggesting that the vector was disrupted during cloning, whereas the causes were unknown.

Human EF $1 \alpha$ promoter is a very strong and non-tissue specific promoter. Therefore, human EF1 $\alpha$-drived transgene (the mutant $B M P R 1 B$ ) is expected to be highly expressed in multiple tissues. Indeed, we found the expression of the introduced mutant allele $(746 G)$ in 8 tissues (Supplementary Figure S1). Moreover, the western blot data showed that the protein expression levels in all detected tissues were higher in transgene-positive individuals (Supplementary Figure S2) than in negative ones (Figure 5). The overexpression of the mutant BMPRIB in multiple tissues could have undesirable effects on transgenic positive individuals. Nevertheless, those transgenic pigs showed comparable growth and immune traits with negative ones (data not shown).

As only pig No. 11 contained the complete promoter and CDS regions of the transgenic vector, we selected it to cross with wild-type Large White sows to produce $F_{1}$ pigs. The litter size data indicated that the No. 11 founder boar had good litter size performance, averaging 12.77 and 11.85 of TNB and NBA (Table 3), respectively. Positive and negative $F_{1}$ sows had lower TNB and NBA (positive: 11.22 TNB and 9.11 NBA; negative: 12.10 TNB and 10.20 NBA; Table 3) and higher NSB than the $F_{0}$ group. This may be due to the half-sib mating of the $F_{1}$ groups or small sample size. The $\mathrm{F}_{1}$ positive sows had slightly lower TNB and NBA, as well as slightly higher number of NW, NM, and NSB than the negative ones, but not statistically different. We deduce that this was possibly due to the disruption of $\mathrm{N}$ acetylglucosaminidase $(N A G L U)$ gene by the integration site on SSC12 or small sample size. NAGLU has been implicated in Sanfilippo syndrome disease in several mammals including human (Verhoeven et al., 2010), mouse (Langford-Smith et al., 2011), dog (Ellinwood et al., 2003) and cattle (Karageorgos et al., 2007). However, no porcine models for this disease have been reported. Detailed biological effects of disrupting this gene in porcine should be further investigated. Another integration site on SSC13 was located within the large intron $1(97.5 \mathrm{~kb})$ of CMTM8, a potential tumor suppressor gene (Zhang et al., 2012b). Sow litter size has been widely regarded as a complex trait affected by various elements including physiological, genetic and environmental factors and their interactions

Table 4. Semen characteristics of transgene-positive and negative $\mathrm{F}_{1}$ boars (Mean \pm standard error)

\begin{tabular}{lcccc}
\hline & $\begin{array}{c}\text { Semen volume } \\
(\mathrm{mL})\end{array}$ & Sperm motility & $\begin{array}{c}\text { Sperm concentration } \\
(\text { million } / \mathrm{mL})\end{array}$ & $\begin{array}{c}\text { Total sperm per ejaculate } \\
(109)\end{array}$ \\
\hline Positive $(\mathrm{N}=6)$ & $323.59 \pm 12.57$ & $0.87 \pm 0.02$ & $232.34 \pm 21.85$ & $73.36 \pm 7.30$ \\
Negative $(\mathrm{N}=6)$ & $288.55 \pm 12.79$ & $0.87 \pm 0.01$ & $225.21 \pm 12.41$ & $62.61 \pm 2.55$ \\
$\mathrm{p}$ value & 0.06 & 0.87 & 0.78 & 0.18 \\
\hline
\end{tabular}


(Urban et al., 1966; Leymaster and Bennett, 1994; Humpolicek et al., 2012), thus large numbers of litters are required to accurately estimate the litter size performance between transgene-positive and negative sows. In addition, as introns are considered a safer location to contain exogenous genes (Renault and DuChateau, 2013; Awe et al., 2014), we should further identify the transgene-positive sows with only a SSC13 integration site for comparing litter size performance with transgene-negative sibling sows.

It has been shown that Garole $\times$ Malpura rams with $B M P R 1 B$ A746G genotype have higher sperm concentration than those with wild genotype (Kumar et al., 2007). In this study, we compared routine semen characteristics including semen volume, sperm motility, sperm concentration and total sperm per ejaculate between full-sib $F_{1}$ positive and negative boars. To accurately compare the semen characteristic data, 6 positive and 6 negative boars with good health conditions were chosen from three full-sib litters. In addition, all boars were blind-labeled to the experimenters. Semen was collected in the same period for all boars by the same personnel. The data showed that the positive ones had the same mean value of sperm motility as the negative individuals. Interestingly, the positive boars had higher semen volume, sperm concentration and total sperm per ejaculate than the negative ones, but with no significant difference (Table 4). This phenotype is similar to the findings in rams reported by Kumar et al. (Kumar et al., 2007). Although most function studies for bone morphogenetic protein genes were focused on female reproduction traits, there were a few reports indicating that these genes also play important roles on male reproduction traits (Shimasaki et al., 2004). Our study provides new proof that BMPRIB may be involved in important functions of male reproduction in mammals.

To our knowledge, there are no reports on litter size and semen quality performance of cloned transgenic pigs. It has been reported that Large White sows in Canada had an average of 13.4 TNB and 11.5 NBA at the first parity (2014 Annual Report of Canada Center for Swine Improvement, https://www.ccsi.ca/meetings/annual/Annualreport_2014_E N.pdf). In our study, Large White sows from Canada that mated with the transgenic founder boar showed similar litter size performance (12.77 TNB and 11.85 NBA for the first to second litters). In addition, the $\mathrm{F}_{1}$ positive and negative sows also showed good TNB performance (11.22 for positive and 12.10 for negative sows, Table 3 ), though they were inseminated by half-sib mating. The sperm production between different studies are variable in commercial Large White boars. For example, Czech and Polish Large White boars have an average of $101.3 \times 10^{9}$ total sperm per ejaculate (Wolf and Smital, 2009) and Polish Large White boars have $82.93 \times 10^{9}$ (Knecht et al., 2014). In this study, the transgene-positive $F_{1}$ boars had an average of $73.36 \times 10^{9}$ of total sperm per ejaculate and negative ones had $62.61 \times$ $10^{9}$, both lower than the reported data from commercial wild-type Large White boars. This may be due to the breeding, management and climatic differences among different breeds.

In this study, we successfully introduced a missense mutation related to sheep prolificacy into porcine genome, expecting the host sows to exhibit better litter size performance. However, the positive sows showed slightly poorer litter size traits than the negative ones. This may be partly due to the unfavorable insertion site of the exogenous vector. In recent years, CRISPR/Cas9-mediated genome engineering technology has been widely used by scientists all over the world because of its high precision and efficiency of genome editing. This system may be a useful tool to precisely introduce point mutations into porcine genome.

\section{CONCLUSION}

In conclusion, we obtained 24 cloned transgenic pigs with the modified porcine BMPR1B CDS using HMC. Only one surviving boar (No. 11) had the full promoter and the $B M P R 1 B$ CDS regions, and the transgenic vector was most likely disrupted during the cloning. cDNA sequencing and Western blot indicated that the exogenous BMPRIB CDS was successfully expressed in host pigs. No. 11 founder boar had normal litter size performance. Unexpectedly, transgenic positive $F_{1}$ sows showed slightly poorer litter size performance than the negative ones, probably due to the disruption of a functionally important gene or the small sample size. $F_{1}$ positive boars showed better sperm producing ability than negative individuals, but with no statistical significance. Our study provides new insights into production of cloned transgenic pigs related to reproductive traits.

\section{CONFLICT OF INTEREST}

We certify that there is no conflict of interest with any financial organization regarding the material discussed in the manuscript.

\section{ACKNOWLEDGMENTS}

This work was supported by grants from National Key Research Program of China (2014ZX08006-005) and Science and Technology Supporting Program of Jiangxi Province (20121BBF60030).

\section{REFERENCES}

Atala, A., R. Lanza, J. A. Thomson, and R. Nerem. 2011. 
Principles of Regenerative Medicin. 2nd edn. Elsevier Academic Press, Burlington, MA, USA.

Awe, J. P., A. Vega-Crespo, and J. A. Byrne. 2014. Derivation and characterization of a transgene-free human induced pluripotent stem cell line and conversion into defined clinical-grade conditions. J. Vis. Exp. e52158.

Chen, C. M., K. B. Choo, and W. T. K. Cheng. 1995. Frequent deletions and sequence aberrations at the transgene junctions of transgenic mice carrying the papillomavirus regulatory and the sv40 tag gene sequences. Transgenic. Res. 4:52-59.

Cho, B., O. J. Koo, J. I. Hwang, H. Kim, E. M. Lee, S. Hurh, S. J. Park, H. Ro, J. Yang, C. D. Surh, A. J. D'Apice, B. C. Lee, and C. Ahn. 2011. Generation of soluble human tumor necrosis factor-alpha receptor $1-\mathrm{fc}$ transgenic pig. Transplantation 92:139-147.

Chu, M., L. Jia, Y. Zhang, M. Jin, H. Chen, L. Fang, R. Di, G. Cao, T. Feng, Q. Tang, Y. Ma, and K. Li. 2011. Polymorphisms of coding region of bmpr-ib gene and their relationship with litter size in sheep. Mol. Biol. Rep. 38:4071-4076.

Chu, M. X., X. H. Zhao, Y. J. Zhang, M. Jin, J. Y. Wang, R. Di, G. L. Cao, T. Feng, L. Fang, Y. H. Ma, and K. Li. 2010. Polymorphisms of bmpr-ib gene and their relationship with litter size in goats. Mol. Biol. Rep. 37:4033-4039.

Davis, G. H. 2005. Major genes affecting ovulation rate in sheep. Genet. Sel. Evol. 37:S11-S23.

Du, Y., P. M. Kragh, Y. Zhang, J. Li, M. Schmidt, I. B. Bogh, X. Zhang, S. Purup, A. L. Jorgensen, A. M. Pedersen, K. Villemoes, H. Yang, L. Bolund, and G. Vajta. 2007. Piglets born from handmade cloning, an innovative cloning method without micromanipulation. Theriogenology 68:1104-1110.

Ellinwood, N. M., P. Wang, T. Skeen, N. J. H. Sharp, M. Cesta, S. Decker, N. J. Edwards, I. Bublot, J. N. Thompson, W. Bush, E. Hardam, M. E. Haskins, and U. Giger. 2003. A model of mucopolysaccharidosis iiib (sanfilippo syndrome type iiib): Nacetyl-alpha-d-glucosaminidase deficiency in schipperke dogs. J. Inherit. Metab. Dis. 26:489-504.

Forsberg, C. W., R. G. Meidinger, M. Liu, M. Cottrill, S. Golovan, and J. P. Phillips. 2013. Integration, stability and expression of the e. Coli phytase transgene in the cassie line of yorkshire enviropig. Transgenic. Res. 22:379-389.

Gaj, T., C. A. Gersbach, and C. F. Barbas, 3rd. 2013. Zfn, talen, and crispr/cas-based methods for genome engineering. Trends. Biotechnol. 31:397-405.

Golovan, S. P., R. G. Meidinger, A. Ajakaiye, M. Cottrill, M. Z. Wiederkehr, D. J. Barney, C. Plante, J. W. Pollard, M. Z. Fan, M. A. Hayes, J. Laursen, J. P. Hjorth, R. R. Hacker, J. P. Phillips, and C. W. Forsberg. 2001. Pigs expressing salivary phytase produce low-phosphorus manure. Nat. Biotechnol. 19:741-745

Gordon, J. W., G. A. Scangos, D. J. Plotkin, J. A. Barbosa, and F. H. Ruddle. 1980. Genetic transformation of mouse embryos by microinjection of purified DNA. Proc. Natl. Acad. Sci. USA. 77:7380-7384.

Guthrie, H. D., R. J. Wall, V. G. Pursel, J. A. Foster-Frey, D. M. Donovan, H. D. Dawson, G. R. Welch, and W. G. Garrett. 2005. Follicular expression of a human beta-cell leukaemia/lymphoma-2 (bcl-2) transgene does not decrease atresia or increase ovulation rate in swine. Reprod. Fertil. Dev. 17:457-466.

Hammer, R. E., V. G. Pursel, C. E. Rexroad, Jr., R. J. Wall, D. J.
Bolt, K. M. Ebert, R. D. Palmiter, and R. L. Brinster. 1985. Production of transgenic rabbits, sheep and pigs by microinjection. Nature 315:680-683.

Humpolicek, P., Z. Tvrdon, and J. Jaros. 2012. Impact of wean to standing reflex interval on litter size of sows. Arch. Tierz. 55:148-151.

Karageorgos, L., B. Hill, M. J. Bawden, and J. J. Hopwood. 2007. Bovine mucopolysaccharidosis type iiib. J. Inherit. Metab. Dis. 30:358-364.

Knecht, D., S. Środoń, and K. Duziński. 2014. The influence of boar breed and season on semen parameters. S. Afr. J. Anim. Sci. 44(1):1-9.

Kumar, D., A. Joshi, S. M. Naqvi, S. Kumar, A. K. Mishra, V. P. Maurya, A. L. Arora, J. P. Mittal, and V. K. Singh. 2007. Sperm motion characteristics of garolexmalpura sheep evolved in a semi-arid tropical environment through introgression of fecb gene. Anim. Reprod. Sci. 100:51-60.

Lai, L., J. X. Kang, R. Li, J. Wang, W. T. Witt, H. Y. Yong, Y. Hao, D. M. Wax, C. N. Murphy, A. Rieke, M. Samuel, M. L. Linville, S. W. Korte, R. W. Evans, T. E. Starzl, R. S. Prather, and Y. Dai. 2006. Generation of cloned transgenic pigs rich in omega-3 fatty acids. Nat. Biotechnol. 24:435-436.

Langford-Smith, A., M. Malinowska, K. J. Langford-Smith, G. Wegrzyn, S. Jones, R. Wynn, J. E. Wraith, F. L. Wilkinson, and B. W. Bigger. 2011. Hyperactive behaviour in the mouse model of mucopolysaccharidosis iiib in the open field and home cage environments. Genes. Brain. Behav. 10:673-682.

Leymaster, K. A. and G. L. Bennett. 1994. An approach to select for litter size in swine: conceptual, theoretical, and applied aspects. Proc. 43 rd Annu. Natl. Breed. Roundtable, St. Louis, MO, USA. pp. 54-64.

Mark, W. H., K. Signorelli, M. Blum, L. Kwee, and E. Lacy. 1992. Genomic structure of the locus associated with an insertional mutation in line 4 transgenic mice. Genomics 13:159-166.

Mulsant, P., F. Lecerf, S. Fabre, L. Schibler, P. Monget, I. Lanneluc, C. Pisselet, J. Riquet, D. Monniaux, I. Callebaut, E. Cribiu, J. Thimonier, J. Teyssier, L. Bodin, Y. Cognie, N. Chitour, and J. M. Elsen. 2001. Mutation in bone morphogenetic protein receptor-ib is associated with increased ovulation rate in booroola merino ewes. Proc. Natl. Acad. Sci. USA. 98:5104-5109.

Nakanishi, T., A. Kuroiwa, S. Yamada, A. Isotani, A. Yamashita, A. Tairaka, T. Hayashi, T. Takagi, M. Ikawa, Y. Matsuda, and M. Okabe. 2002. Fish analysis of 142 egfp transgene integration sites into the mouse genome. Genomics 80:564-574.

Prather, R. S., M. Shen, and Y. Dai. 2008. Genetically modified pigs for medicine and agriculture. Biotechnol. Genet. Eng. Rev. 25:245-265.

Renault, S. and P. DuChateau. 2013. Site-Directed Insertion of Transgenes (1st Edn). Springer Science Business Media, Dordrecht, Netherlands.

Renner, S., C. Fehlings, N. Herbach, A. Hofmann, D. C. von Waldthausen, B. Kessler, K. Ulrichs, I. Chodnevskaja, V. Moskalenko, W. Amselgruber, B. Goke, A. Pfeifer, R. Wanke, and E. Wolf. 2010. Glucose intolerance and reduced proliferation of pancreatic beta-cells in transgenic pigs with impaired glucose-dependent insulinotropic polypeptide function. Diabetes 59:1228-1238.

Shimasaki, S., R. K. Moore, F. Otsuka, and G. F. Erickson. 2004. The bone morphogenetic protein system in mammalian 
reproduction. Endocr. Rev. 25:72-101.

Sommer, J. R., J. L. Estrada, E. B. Collins, M. Bedell, C. A. Alexander, Z. Yang, G. Hughes, B. Mir, B. C. Gilger, S. Grob, X. Wei, J. A. Piedrahita, P. X. Shaw, R. M. Petters, and K. Zhang. 2011. Production of elovl4 transgenic pigs: A large animal model for stargardt-like macular degeneration. Br. J. Ophthalmol. 95:1749-1754.

Souza, C. J., C. MacDougall, C. MacDougall, B. K. Campbell, A. S. McNeilly, and D. T. Baird. 2001. The booroola (fecb) phenotype is associated with a mutation in the bone morphogenetic receptor type $1 \mathrm{~b}$ (bmprlb) gene. J. Endocrinol. 169:R1-R6.

Urban, W. E., C. E. Shelby, A. B. Chapman, J. A. Whatley, and V. A. Garwood. 1966. Genetic and environmental aspects of litter size in swine. J. Anim. Sci. 25:1148-1153

Vajta, G., P. Bartels, J. Joubert, M. de la Rey, R. Treadwell, and H. Callesen. 2004. Production of a healthy calf by somatic cell nuclear transfer without micromanipulators and carbon dioxide incubators using the handmade cloning $(\mathrm{hmc})$ and the submarine incubation system (sis). Theriogenology 62:14651472.

Verhoeven, W. M., R. Csepan, C. L. Marcelis, D. J. Lefeber, J. I. Egger, and S. Tuinier. 2010. Sanfilippo $b$ in an elderly female psychiatric patient: A rare but relevant diagnosis in presenile dementia. Acta Psychiatr. Scand. 122:162-165.

Watanabe, M., M. Kurome, H. Matsunari, K. Nakano, K. Umeyema, A. Shiota, H. Nakauchi, and H. Nagashima. 2012. The creation of transgenic pigs expressing human proteins using bac-derived, full-length genes and intracytoplasmic sperm injection-mediated gene transfer. Transgenic. Res. 21:605-618.
Wolf, J. and J. Smital. 2008. Quantification of factors affecting semen traits in artificial insemination boars from animal model analyses. J. Anim. Sci. 87:1620-1627.

Xing, Y., J. Ren, D. Ren, Y. Guo, Y. Wu, G. Yang, H. Mao, B. Brenig, and L. Huang. 2009. A whole genome scanning for quantitative trait loci on traits related to sperm quality and ejaculation in pigs. Anim. Reprod. Sci. 114:210-218.

Yang, C. X. and J. W. Ross. 2012. Genetic modification of domestic animals for agriculture and biomedical applications. Biomedical Science, Engineering And Technology (Dhanjoo N. Ghista). Intech, Rijeka, Croatia. 697-726.

Yang, D., C. E. Wang, B. Zhao, W. Li, Z. Ouyang, Z. Liu, H. Yang, P. Fan, A. O'Neill, W. Gu, H. Yi, S. Li, L. Lai, and X. J. Li. 2010. Expression of huntington's disease protein results in apoptotic neurons in the brains of cloned transgenic pigs. Hum. Mol. Genet. 19:3983-3994.

Yeom, H. J., O. J. Koo, J. Yang, B. Cho, J. I. Hwang, S. J. Park, S. Hurh, H. Kim, E. M. Lee, H. Ro, J. T. Kang, S. J. Kim, J. K. Won, P. J. O'Connell, H. Kim, C. D. Surh, B. C. Lee, and C. Ahn. 2012. Generation and characterization of human heme oxygenase-1 transgenic pigs. PLoS One 7:e46646.

Zhang, P., Y. Zhang, H. Dou, J. Yin, Y. Chen, X. Pang, G. Vajta, L. Bolund, Y. Du, and R. Z. Ma. 2012a. Handmade cloned transgenic piglets expressing the nematode fat-1 gene. Cell. Reprogram. 14:258-266.

Zhang, W., M. C. Mendoza, X. Pei, D. Ilter, S. J. Mahoney, Y. Zhang, D. Ma, J. Blenis, and Y. Wang. 2012b. Downregulation of cmtm8 induces epithelial-to-mesenchymal transition-like changes via c-met/extracellular signal-regulated kinase (erk) signaling. J. Biol. Chem. 287:11850-11858. 